\title{
PISANIE Z KACEM I KATZEM
}

ŚLĄSKI

PRZEGLĄD

STATYSTYCZNY

Ludomir Laudański

Nr 15(21)

Emerytowany profesor Politechniki Rzeszowskiej

ISSN 1644-6739

e-ISSN 2449-9765

DOI: $10.15611 /$ sps.2017.15.15

Motto:

Oh, baby, baby - what's inside a girl?

O tym, że jest taki matematyk - Mark Kac (1914-1984) - wiedziałem od początku lat 60., gdy ujrzałem w pionierskiej pracy Stephena O. Rice'a (1907-1986), zatytułowanej Teoria fluktuacyjnych szumów (Mathematical Analysis of Random Noise, 1944 i 1945 ) - odnośnik do pracy Kaca opublikowanej w 1943 roku w USA [Kac 1943]. W moim ręku znalazł się przekład - z roku 1953 - obu artykułów Rice'a na język rosyjski Теория передачи электрических сигналов при наличии помех [Железнова 1953] - a wtedy jeszcze Moskale potrzebowali 10 lat, aby wiedzieć, kto to jest Kac, jego nazwisko zaś zapisywali fonetycznie - jako „М. КэК”. To był początek. A kulminacja moich związków z Kacem wypadła na jego wizyty w Polsce jesienią 1972 - do czego symbolicznie nawiązuje Jabłonna, i latem 1973 - Kamienny Potok. Obie powiązane z moim pierwszym przełożonym Władysławem Fiszdonem (1912-2004). Kontakt ten na nowo „odżył” dopiero po śmierci Kaca - gdy latem 1996 przywiozłem z USA wydany pośmiertnie w 1985 roku pamiętnik Kaca Enigmas of Chance [Kac 1985]. Ta autobiografia eksponuje Kaca - Amerykanina. Natomiast ostatnio natknąłem się w Internecie na anonimowy biogram M. Kaca, zaskakujący czytelnika przechyłem - podnoszącym jego polskość. Tak więc tu się rysuje pierwszy - może jeszcze i płytki Split osobowy. Więc mój tekst mógłby się odnieść do pytania: jak to było z tą polskością Kaca - na pół wiecznym przedziale, pogłębionym o znajomość monografii Konecznego Cywilizacja żydowska [Koneczny 1997]. Spróbowałbym pisać bez ograniczeń co do objętości, przyjąc 'swobodną rękę' - na usprawiedliwienie mając zachętę samego M. Kaca - aby napisać po jego śmierci Obituary. Aliści jeśli przywołam własny kilkustronicowy tekst opublikowany w 'Szkicach Polskich' [Laudański 2005], zatytułowany Bomby Stanisława Ulama, w którym - wbrew tytułowi - tyleż Ulama, ileż i Kaca, to zarysuje się coś więcej. Najpierw jawi się to 'coś' jako wzmocnione echo opinii 
Kaca napomkniętej w moim szkicu z tego samego źródła - poświęconym Heglowi. Wspomniałem tam, że Kac, odpowiadając na ankietę Science, użył jako wyrażenia synonimicznego teorii katastrof Rene Thoma (1923-2002) określenia: szczyt naukowej nieodpowiedzialności (tu przywołuję [Thom 1975]). Radykalne, bezkompromisowe. Idąc tym nowym śladem - Bomby Stanisława Ulama przedstawiają znacznie szerszą wypowiedź Kaca z kart autobiografii Enigmas of Chance, którą Kac powtarza za Erwinem Chargaffem (1905-2002), gdy ten publicznie określa odkrywców spirali DNA - Jamesa Watsona (ur. 1928) i Francisa Cricka (1916-2004), uhonorowanych Nagrodą Nobla - mianem ,a couple of upstarts who were scientific plumbers”. Teraz, nad Wisłą - byłaby to poważna obraza! A w ten sposób rysuje się nam wizja znacznie głębszego splitu - rozdwojenia, może nawet schizofrenicznego - osobowości Kaca. W jednej apostazie jawi się nam jako jowialny pan - pełen uroku, lubiący gawędzić, chętnie posługujący się facecją, ceniący radości stołu i kompanii. Taki Kac był znany Wiliamowi Searsowi (1913-2002) z ich wspólnych lat (1946-1960) na Cornell, lat, którym Sears w swej autobiografii Stories from a 20th Century Life [Rees Sears 1994], wydanej za swego życia - w 1994 roku poświęca dwa rozdziały. Dowiadujemy się w nich o ich przyjaźni, wzajemnych wizytach, a Sears określa Kaca mianem 'master storyteller'. Natomiast na kartach Enigmas of Chance darmo szukać Searsa. Kac, nawet choćby za pośrednictwem 'footnote', Searsa nie wspomina - jakby nosząc gdzieś wewnątrz sekretną misję, kształt której może się jedynie mgliście zarysować: misję będącą bezkompromisową, nieustępliwą, 'starotestamentową' wizją ludzi i świata. Czy więc z tego powodu, jeśli założymy, że trudno, aby Sears nie znał autobiografii Kaca wydanej znacznie wcześniej, nie chciał świadomie mówić pośmiertnie o takim człowieku, jaki jawi się na kartach tej autobiografii? Ha! Tak więc biorąc na warsztat zadanie przedstawienia tej postaci postaci Marka Kaca - musimy się zmierzyć z kłopotliwym wyzwaniem i w jakiś sposób jednak się do dylematu 'splitu osobowego' Kaca ustosunkować! Wsparcie będą stanowiły materiały źródłowe znajdujące się w moich prywatnych zbiorach, skrupulatnie gromadzonych w ciągu około 50 lat.

1. Сборник статей. Под редакцией: Н.А. Железнова, 1953, Теория передачи электрических сигналов при наличии помех, Издательство Инностранной Литературы, Москва.

2. Кац М., 1965, Вероятность и смежные вопросы в физике, Издательство Мир, Москва. Tytuł oryginału: Probability and Related Topics in Physical Sciences, by Mark Kac, Interscience. 
3. Кац М., 1963, Статистическая независимость в теории вероятностей анализе и теории чисел. Издательство Инностранной Литературы, Москва. Tytu1 oryginału: Statistical Independence in Probability, Analysis and Number Theory, by Mark Kac, The Mathematical Association of America, 1959, polski przekład K. Akst-Lipszyc, redaktor naukowy Z. Ciesielski, Niezależność statystyczna $w$ rachunku prawdopodobieństwa, analizie i teorii liczb, Fundacja Rozwoju Matematyki Polskiej, Warszawa 1992. Dodatek autorstwa H.P. McKeana z biogramem i spisem publikacji 'Mark Kac (16 sierpnia 1914-25 października 1984)'.

4. Кац М., Улам С., 1971, Математика и логика. Ретроспектива и перспективы. Под редакиией Ибрагима Моисеевича Яглома, Издательство „Мир”, Москва, s. 253. Oryginał: M. Kac and S.M. Ulam: Mathematics and Logic. Retrospect and Prospects, Frederick A. Praeger, Publishers, New York 1968.

5. Kac M., 1961, Kilka zagadnień stochastycznych fizyki i matematyki, PWN, Warszawa. Tytuł oryginału: Some Stochastic Problems in Physics and Mathematics, 1956, przekład L. Kubika, Słowo wstępne M. Fisza i przedmowa autora do polskiego wydania.

6. Ulam S.M., 1976, Adventures of a Mathematician, the autobiography of the famous Polish mathematician, illustrated with photographes, Charles Scribner Sons, New York with preface to the 1983 edition, s. 317.

7. Kac M., 1985, Enigmas of Chance, an Autobiography, Harper and Row, New York.

8. Rees Sears W., 1994, Stories from a 20th-Century Life, Parabolic Press, Stanford.

9. Laudański L.M., 2012, Aeroelastyczność płatowca. Aspekt meteorologiczny, Oficyna Wydawnicza P.Rz., Rzeszów (rozdział 5: „Statystyki progowe - zmęczenie”, s. 199-202).

10. Kac M., 1943, On the average number of real roots of a random algebraic equation, Bulletin American Mathematical Society, vol. 49, pp. 314-320, corrections.

11. Laudański L., 1967, O liczbowych charakterystykach funkcji losowych w zastosowaniu do badań obciażeń samolotu, Archiwum Budowy Maszyn, tom XIV, zeszyt 1, s. 49-58.

12. Herczyński R., Pieńkowska I. (red.), 1974, Teorie statystyczne $w$ ciałach statych cieczach i gazach, Ossolineum, PAN, Wrocław materiały konferencji szkoleniowej, Jabłonna, 4-16 września 1972.

13. Kac M., 1993, Marian Smoluchowski a ewolucja idei statystycznej w fizyce, Roczniki PTM, Seria II: Wiadomości Matematyczne, XXX.1, Warszawa, s. 85-91.

14. Refleksje polskich mistrzów - wywiad ze Stanisławem Ulamem i Markiem Kacem przeprowadzony przez Mitchella Feigenbauma, 1982, opublikowany 'Los Alamos Science' vol., no. 3; w postaci przekładu wydrukowany w 'Postępach Fizyki' 1984, vol. 35, s. 495-513; przedruk - Roczniki PTM, Seria II: Wiadomości Matematyczne, XXX.1, Warszawa 1993, s. 93-114.

15. Laudański L.M., 2005, Szkice Polskie, Oficyna Wydawnicza P.Rz., Rzeszów.

16. Koneczny F., 1997, Cywilizacja żydowska, Wydawnictwo „Antyk” Marcin Dybowski, Komorów.

17. Steinhaus H., 2002, Wspomnienia i zapiski, wydanie II, w opracowaniu A. Zgorzelskiej, przypisy zestawił i redagował R. Duda. Oficyna Wydawnicza ATUT, Wrocław.

18. Thom R., 1975, Structural Stability and Morphogenesis, translated from the French edition, as updated by the author, by D.H. Fowler, W.H. Benjamin, Reading.

19. Bieńkowska A., 2012, Juliusz Poniatowski. Biografia polityczna, Wydawnictwo Neriton, Warszawa, s. $406+8$ wklejek ze zdjęciami. 
ŚLĄSKI

PRZEGLĄD STATYSTYCZNY

Nr 15(21)

20. Drozdowski M.M., 2012, Juliusz Poniatowski (1886-1975), Muzeum Historii Polskiego Ruchu Ludowego, Warszawa.

21. Spętana Akademia. Polska Akademia Nauk w dokumentach władz PRL, 2009, materiały Służby Bezpieczeństwa (1967-1987), tom 1, IPN, Warszawa.

22. Kobyliński S., Ziółkowska-Bohm A., 2003, Nie minęło nic, oprócz lat, Wydawnictwo Nowy Świat, Warszawa (książka posiada bardzo dobry indeks osób).

Krótkie i nie nazbyt uładzone komentarze do bibliografii zostaną wtopione $\mathrm{w}$ tekst niniejszego szkicu i będą się z nim przeplatać - a zacznę od tego, że gdy zaprzyjaźniony warszawski matematyk zbierał się A.D. 1968, aby opuścić rodzinną Polskę, wykorzystując 'wiedeńską furtkę' - pozostawił mi w spadku wcale obfity dowód swych zaskakujących zbierackich talentów. Były one zapleczem problematyki, która narodziła się we Lwowie u Hugona Steinhusa (1887-1972) na przełomie lat 1929/30, a którą on przekazał w ręce swego zdolnego doktoranta Marka Kaca w latach 1934-35 i ten ją kontynuował w pierwszym okresie pracy w USA na Cornell (por. [Kac 1943]). Ignacy Kotlarski pozostawił m.in. kilka prac z lat 1966-68, jakie wykonali matematycy, z których L. Arnold pracował w Stuttgarcie, J.E.A. Dunnage w Londynie, a Clifford Qualls w New Mexico - USA. Wszyscy oni znali wspominane tu prace Steinhausa i Kaca. Przyznaję, że dzieliłem swoje zdumienie pomiędzy nieznającą granic ani odległości propagację tych idei, jak i talent Kotlarskiego, pozwalający prace takie wyszukać, nawiązać kontakt z ich autorami i pozyskać kopie tych prac. Podstawowe fakty dotyczącego tego wątku - sygnowanego terminem 'wielomiany o losowych współczynnikach i ich miejsca zerowe' zebrałem w początkowym fragmencie mojej najnowszej książki [Laudański 2012], redagując jej ostatni rozdział poświęcony statystykom progowym. Podjąłem przy tym próbę ratowania tych statystyk w obliczu niefortunnego określania ich terminem 'spektrów' czy jeszcze mniej fortunnie terminem 'widm' - który w odniesieniu do zastosowań w dziedzinie zmęczenia uzyskał wręcz komiczną postać 'widma zmęczeniowego', akceptowanego - można rzec - powszechnie w wielu działach inżynierii. Tematyce tej poświęciłem na początku lat 60 . własną pracę [Laudański 1967], którą rekomendował do druku Kazimierz Urbanik (1930-2005), uważany za najbardziej utalentowanego wrocławskiego wychowanka Hugona Steinhausa. Konkluzja jego recenzji brzmiała: 
„Praca p. L. Laudańskiego wnosi nowe elementy do teorii stacjonarnych funkcji losowych. Jest ścisła i napisana przejrzyście. Uważam, że powinna być ogłoszona drukiem."

Nic dziwnego, że mogłem się nią pochwalić. Jednak ku memu zdumieniu i rozczarowaniu praca ta nie wywołała żadnej reakcji ze strony Kaca - całkowicie ją przemilczał. Powiało mi - nie po raz pierwszy - Konecznym i jego gruntownie przemyślanymi tezami znajdującymi się na kartach [Koneczny 1997]. Może jeszcze bardziej wyraziście wygląalał mój kontakt z kuzynem Szymona Kobylińskiego (1927-2002) - Robertem Bartoszyńskim (1933-1998). Piszę 'kuzyn', aby krótko podsunąć epizod z kart [Kobyliński, Ziółkowska-Bohm 2003], w którym jest mowa o tym, że na ślubie Kobylińskiego grał na akordeonie Bartoszyński. Cóż, ja go poznałem od niezbyt harmonijnej strony. Otóż Bartoszyński, zapoznawszy się z maszynopisem [Laudański 1967], oznajmił - że autor tej pracy 'nie rozwiązał żadnego problemu matematycznego' - a nadto, że praca ta może co najwyżej przedstawiać wartość na nieznanym mu gruncie inżynierii lotniczej ale nie $\mathrm{w}$ matematyce. Chcę $\mathrm{w}$ ten sposób powiedzieć, że $\mathrm{w}$ ciągu mego profesjonalnego 'life time', o którym sprawiedliwie będzie powiedzieć, że dobiega - czy nawet już dobiegł - swego kresu - przyszło mi doświadczać w ocenie tego, co robiłem, tendencyjnej postawy ludzi, którym Koneczny poświęcił całą monografię [1997], a niejednokrotnie doświadczenie to miało dla mnie znaczący, a w kilku wypadkach nawet decydujący charakter. Najczęściej zaś wykorzystywanym narzędziem, które tu wchodziło w rachubę, były recenzje, a w wersji mniej nośnej - ustne opinie ewaluujące jakąś pracę. W tym kontekście wypada przytoczyć, w jaki sposób Marek Kac, po zapoznaniu się z maszynopisem pierwszego tomu mojej Mechaniki porzadkiem geometrycznym wyłożonej, podczas wspólnego pobytu na konferencji szkoleniowej w Jabłonnej, jesienią 1972 - on jako wykładowca, a ja jako słuchacz - ujął swoją opinię we frazę z pozoru żartobliwą, że 'polska mechanika doczekała się swego Jana Chryzostoma Paska'. I choć najłatwiej się pisze, przywołując własne zapisy pamięciowe, skieruję się teraz ku opracowaniu, którego publikację zawdzięczamy wrocławskiemu ośrodkowi naukowemu, a mam na myśli osobliwe Wspomnienia i zapiski Hugona Steinhausa [2002]. W niniejszym kontekście bardzo pomocny jest indeks nazwisk wielkiej mnogości postaci przywoływanych przez Steinhausa. Można ich liczbę oszacować następująco: 30 stron indeksu, a na każdej stronie 50 nazwisk prowadzi do dolnego szacunku 1500 osób. Wrocławskie wyda- 
nie Wspomnień i zapisków [Steinhaus 2002] budzi mieszane uczucia, a ich redakcja nie pomaga $w$ recepcji tej bogatej zawartości. Wystarczyło - dla przykładu - umieścić czytelny śródpodział oparty na datach stanowiących chronologiczny układ 'Wspomnien'. Należało dołączyć choćby schematyczny biogram autora i jednak podzielić Wspomnienia $i$ zapiski na dwa tomy. Wreszcie sama już szata edytorska - mimo dumnych nadruków, że edycję wsparła finansowo Polska Akademia Umiejętności oraz Politechnika Wrocławska. Cóż z tego, skoro wsparcie to wystarczyło tylko na skromny 'paper-back', a klejone na grzbiecie kartki zapewne niedługo się rozlecą.

$\mathrm{Z}$ niniejszego punktu widzenia zasadnicze znaczenie ma zestaw odsyłaczy dotyczących Marka Kaca, przywołujący blisko 25 stron Wspomnień, niestety najczęściej mieszczących się w jednym wierszu. Jest jedno powołanie dotyczące Juliusza Poniatowskiego. W tej ostatniej kwestii pomożemy sobie dwiema świeżymi publikacjami biograficznymi: Alicji Bieńkowskiej [2012] i Mariana Drozdowskiego [2012] oraz własnymi zapisami pamięciowymi, no i autobiografią Kaca [1985]. Wspomnę teraz powołanie na stronach 154-156 [Steinhaus 2002] - jedyne, które w sposób istotny nawiązuje do owego wczesnego okresu współpracy naukowej Kaca i Steinhausa. Aliści Steinhaus pisze - wbrew swym apologetom - niestety dość chaotycznie i przywołany ustęp jest tego przykładem. Choć dowiadujemy się, że w roku 1938 Steinhaus uzyskał dla Kaca stypendium w Ameryce, to nie znajdziemy żadnych szczegółów, ale - co istotne - te dwie strony przynoszą relację z pobytu Steinhausa (razem z córką) w Krzemieńcu. Jadą tam na zaproszenie Kaca, aby nim opuści on Polskę, razem nachylić się nad tematyką 'funkcji niezależnych'. 'Codziennie po parę godzin gadaliśmy' - mówi ten Dobry Człowiek, wyjaśniając: 'Nie była to praca nad konkretnym zagadnieniem, lecz próbowanie nowych definicji i koncepcji; najbardziej pasjonujący rodzaj pracy.' Ani słowa więcej. Steinhaus opisał rodzinę, z której wyszedł Marek. $\mathrm{Z}$ jego młodszym bratem (nie znamy imienia) - licealistą - grywał $\mathrm{w}$ tenisa. Ojciec Kaca - z doktoratem uzyskanym w Lipsku - uczył w liceum religii. Kac odpłynął do Ameryki. Gdy Steinhaus (zob. s. 511 Wspomnień) w roku 1961, gościł, na zaproszenie Kaca, w Nowym Yorku w Rockefeller University (obchodził tam 50-lecie swego getyngeńskiego doktoratu), Kac zwrócił się do niego, przypominając mu słowa, którymi Steinhaus żegnał go przed podróżą do USA:

You have a right to go - I have to stay because somebody must stay. 
Kilka lat wcześniej - w roku 1958 - Kac, publikując pracę [Кац 1965], napisał душощиипательную dedykację, którą tu przytaczam z $\mid$ Nr 15(21) rosyjskiego przekładu:

\section{Памяти моих родителей и моего брата невинных жертв войны.}

Był taki moment w roku 1973, gdy prof. W. Fiszdon gościł w swym dawnym gabinecie w IPPT (który musiał opuścić w roku 1968) Marka Kaca. Powiedział wtedy do mnie, gdy wchodząc, witałem się z nimi, że obaj są 'krzemieńczykami', a potem dodał, że Kac jest takim naukowcem, który nie utrzymuje żadnych kontaktów z Niemcami wstrzymuje się nawet od rozmów z nimi. Na to ja - chcąc nieco odciążyć atmosferę - powiedziałem, że ja się posunąłem może jeszcze dalej, bo nawet nie używam języka niemieckiego. Kac parsknął śmiechem i atmosfera stała się cokolwiek lżejsza. Razem z tym wciąż pozostawiamy tu na boku Konecznego, ale on - chcąc nie chcąc - nie pozwala o sobie zapomnieć. Oto w jednym ze spotkań z Juliuszem Poniatowskim, na świeżo po spotkaniu z Kacem, usłyszałem taką opinię - cytuję w przybliżeniu słowa Poniatowskiego: 'Marek należał do tego pokolenia polskich Żydów, które wyniosło z tej przynależności same korzyści'. Wspomnę więc, jak to - nie znajdując $\mathrm{w}$ dwu warszawskich restauracjach miejsca na spożycie obiadu, zaraz po tym, jak mój pierwszy przełożony przekazał Kaca pod moją kuratelę, dodając, że Kac w USA uczestniczy w dwu instytucjach przyznających stypendia na naukowe staże - zaprosiłem go 'dyplomatycznie' do swego mieszkania. Zamiast restauracyjnego obiadu zjedliśmy doskonałego śledzika 'Norda' ze świeżą cebulką w towarzystwie pysznego polskiego chleba - z prywatnej piekarenki - smarowanego pachnącym 'bazarowym' masłem, dodając do tego tarty przeze mnie osobiście chrzan w śmietanie, a dla 'kurażu' posmakowaliśmy łyk koszernej pejsachówki. Widać było, że Kac to wszystko umiał docenić. Ale nic więcej. Wiedziałem, że w Krzemieńcu - rodzinnym mieście Kaca - za lat licealnych przyjaźnił się on z Barbarą (1914-1944) - córką ówczesnego kuratora liceum, swą rówieśniczką; razem pobierali tam nauki aż do samej matury. Ale wiedziałem też, że Barbara zginęła zaraz w pierwszych dniach powstania warszawskiego, i to na Starówce, gdzie 'operowali' własowcy słynący z okrucieństw i gwałtów - również względem cywilnej ludności. Wiedziałem, że nawet nie potrafiono ustalić miejsca jej mogiły. W ascetycznie urządzonym małym pokoiku Juliusza Poniatowskiego przy Marszałkowskiej 140 m. 32 (w mieszkanku jego brata), obok żelaznego łóżka, stał mały stoliczek, a na nim dwa zdjęcia - marszałka oraz córeczki Barbary jedynego dziecka. W latach 1967-1975 bywałem tam kilka razy i - jak mi 
się wydawało - pozyskałem sympatię gospodarza. Dla ilustracji powiem, że wśród uczestników mego ślubu kościelnego w stołecznym kościele św. Marcina, którzy po zakończeniu ceremonii na wewnętrznym dziedzińcu kościelnym składali nam życzenia, znalazł się Juliusz Poniatowski. Wyniosłem wiele satysfakcji, obcując $\mathrm{z}$ tą eminentną postacią. Całe życie był wierny problematyce rolniczej, bo działalność parlamentarną musiał zakończyć wraz z wrześniem 1939. Znana mi świeżo biografia [Bieńkowska 2012] odświeżyła tamte wspomnienia.

Miałbym kilka niewielkich suplementów do przekazania również $\mathrm{w}$ tej mierze. Jeden z nich dotyczy pytania o pochodzenie - genealogię Poniatowskiego. Autorka opracowania [Bieńkowska 2012] przychyla się do tezy, że pochodził z tego samego pnia co król Stanisław August - pieczętujący się Cielcem. Tymczasem Poniatowski podczas jednego z naszych spotkań oznajmił, że gałąź Poniatowskich, z której pochodzi, wywodzi się ze Śląska Opolskiego. Określił również rodowy klejnot, ale dziś nie potrafię powiedzieć, czy chodziło o Śreniawę. Otóż na kartach autobiografii Kaca jest wyraźnie powiedziane, że kurator Krzemieńca pochodził z królewskiej rodziny. Gdy, z drugiej strony, kontaktowałem się z Kacem, odnosiłem chwilami wrażenie, że wewnętrzny świat Kaca jest całkowicie wypełniony tą polskością, jaką emanowało liceum. Usłyszałem wiele opowieści z tamtych lat. Jedna z nich mówiła, że odkrycie ostatniej planety naszego układu słonecznego - Plutona - co miało miejsce 18 lutego 1930 r. (w amerykańskim obserwatorium stanu Arizona), w liceum wywołało falę zainteresowania astronomią. Wszyscy chcieli po liceum studiować astronomię, co też bardzo wzmocniło szkolne Koło Fizyków. Znam również ustną informację mówiącą o tym, że Władysław Fiszdon, który na roku 1930 kończył edukację w liceum i uzyskał stypendium na studia w Paryżu, aplikował na astronomię, ale z braku miejsca wybrał studia lotnicze.

Wracam do Kaca. Ulubionym poetą Marka Kaca był Juliusz Słowacki (pytał, mnie kogo stawiam na pierwszym miejscu - Mickiewicza czy Słowackiego. Usłyszał, że ja 'uważam' Mickiewicza), w czym swoją zasługę miał tamtejszy polonista (który przeżył II wojnę i Kac utrzymywał, że podczas jednej z wizyt w Polsce się z nim spotkał). Kiedy opowiadał o swych latach w USA, usłyszałem od niego, że gdy bywał w domu Johana von Neumanna (1903-1957), razem słuchali polonezów Ogińskiego - w tym również niezrównanego 'Pożegnania z Ojczyzną', którego trudno słuchać na obczyźnie bez szlochu w piersi. Podczas kilkumiesięcznej walki z rakiem Neumann dokonał przejścia na katolicyzm i w tym obrządku został pochowany. Do jego łoża śmierci przychodził wiele razy Stanisław Ulam, z którym razem pra- 
cowali w Los Alamos i który czytywał mu Wojne peloponeska Tukidydesa w greckim oryginale. A co opisał Ulam w swój autobiografii [1976]? Wiele z tego, co docierało do mnie podczas osobistych kontaktów z Kacem w mierze asymilacji z naszą kulturą, potwierdzałoby zdanie, jakie wypowiedział o Kacu Poniatowski, gdy napomknął 'zdaje się, że jest teraz sławnym w Ameryce matematykiem'. A przy tym charakteryzował Mareczka (jak go nazywał) jako swego licealistę z Krzemieńca. Koneczny utrzymuje, że Żydzi się nie asymilują, a w każdym razie, że takie przypadki, jeśli się nawet zdarzają, mają miejsce wyjątkowo rzadko. Byłbym skłonny sądzić, że taki przypadek mógł reprezentować Stanisław Marcin Ulam (1909-1984). Czy można tę opinię wyrazić o Alfredzie Tarskim (1901-1983)? Para autorska i małżeńska Federmanów w wielkiej i pełnej bogactw biografii Tarskiego, której polski przekład liczy 475 stron, drobiazgowo analizowała ten problem, ale chyba do żadnej wyrazistej konkluzji nie doszła. Natomiast podejrzliwość, jaka zakradała się momentami do mojej jaźni w odniesieniu do Marka Kaca, została lekturą tych dwu autobiografii podsycona. Przemawiałaby też za nią tak wyrazista więź porozumienia, jaka się zarysowała między Kacem i Fiszdonem. Wreszcie ten stan - niepewnej równowagi - chyba ostatecznie przesądzają materiały 'feralnej' IPN-owskiej publikacji [Spętana Akademia...], ukazującej ośrodki skrywanej aktywności Żydów, zwłaszcza w czasie stanu wojennego, zaskakując mnie rolą, jaką w nich odgrywał Władysław Fiszdon - ze stawiającym tym przysłowiową kropkę nad i 'totumfackim' Ryszardem Herczyńskim (1926-2009). Celowo pozostawiłem dywagacje nad podobnym pytaniem w odniesieniu do Hugona Steinhausa - niech inni też mają zajęcie! A my mamy ... aktualne zdjęcie Krzemieńca i murów liceum.

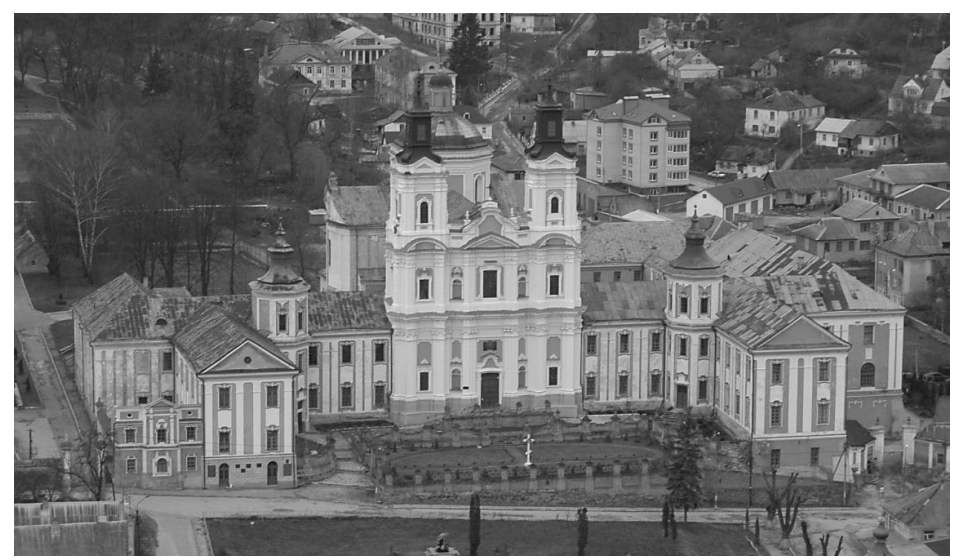

